the immunofluorescence studies, and Dr V Biggs for her advice during the preparation of the manuscript.

${ }^{1}$ Anonymous. Acquired immunodeficiency syndrome [Editorial]. Lancet $1983 ; \mathrm{i}: 162-4$

${ }^{2}$ Levy JA, Ziegler JL. Acquired immunodeficiency syndrome is an opportunistic infection and Kaposi's sarcoma results from secondary immune stimulation. Lancet 1983 ;ii :78-81.

${ }^{3}$ Anonymous. Update on acquired immunodeficiency syndrome (AIDS)United States. $M M W R$ 1982;31:507-8.

4 Brunet JB, Bouret E, Leiboustel J, et al. Acquired immunodeficiency syndrome in France. Lancet $1983 ; \mathrm{i}: 700$.

${ }^{5}$ Mildvan D, Mathur U, Enlow RW, et al. Opportunistic infections and immune deficiency in homosexual men. Ann Intern Med 1982;96:700-4.

(Accepted 3 October 1983)

Medical Unit and Department of Pathology, Western Infirmary, Glasgow G11 6NT

C R SHIACH, BSC, MB, senior house officer

A D BURT, BSC, MB, registrar

C G ISLES, BSC, MRCP, senior registrar

S G BALL, PHD, MRCP, consultant physician

Correspondence to: Dr S G Ball, Medical Research Council Blood Pressure Unit, Western Infirmary.

\section{Risk of giving intravenous aminophylline to acutely ill patients receiving maintenance treatment with theophylline}

Drug monitoring has showr: that the efficacy ${ }^{1}$ of theophylline can be enhanced by maintaining the serum concentration at the upper end of the accepted therapeutic range $(10-20 \mathrm{mg} / \mathrm{l})$. Although the drug is safe when taken over long periods by patients in stable clinical states because its rate of clearance is constant, it may be toxic during acute illnesses, when its rate of clearance may suddenly fall. ${ }^{2}$ Giving an intravenous bolus of aminophylline as emergency treatment to acutely ill patients increases the danger. This was illustrated by a recent case in which the serum theophylline concentration on admission was $64 \mathrm{mg} / \mathrm{l}$ before a bolus of aminophylline was given. ${ }^{3} \mathrm{We}$ undertook the present study to assess the risk of giving intravenous aminophylline to acutely ill patients already receiving oral theophylline.

\section{Patients, methods, and results}

Patients thought by the admitting officer to require emergency treatment with intravenous aminophylline were questioned about their regular drug treatment, and 25 who were receiving oral theophylline were studied. Eleven were subsequently treated with a continuous infusion of aminophylline. We recorded details of drug dosage, dosing interval, and the exact time the last tablet was taken. A $5 \mathrm{ml}$ blood sample was taken, separated, and stored at $-20^{\circ} \mathrm{C}$ for later analysis by enzyme immunoassay (EMIT).

We collected 26 samples from the 25 patients (one patient was admitted twice), who comprised 13 men and 12 women with exacerbations of bronchitis or asthma whose mean (SD) age was 61.7 (17) years. Three patients were smokers; no ex-smoker had smoked within the past three years. The mean daily dose of theophylline was 571 (202) $\mathrm{mg}$ (range 354-992 mg), and the mean time between the last dose and the blood sample was $7 \cdot 7$ (range 1-21) hours.

The table shows the serum theophylline concentrations, which ranged from 2 to $31.2 \mathrm{mg} / \mathrm{l}$; they were below the therapeutic range in 10 samples and within the therapeutic range in 12 . Four patients already had potentially toxic concentrations: two (cases 22 and 15, with concentrations of $25 \mathrm{mg} / 1$ and $31.2 \mathrm{mg} / \mathrm{l})$ had been given $250 \mathrm{mg}$ aminophylline intravenously by their general practitioners one and four hours respectively before admission. A third patient so treated (case 9) had a serum concentration of $11.9 \mathrm{mg} / \mathrm{l}$ four hours after the bolus injection, having taken his usual oral dose $10 \frac{1}{2}$ hours before giving the blood sample.

\section{Comment}

Although only four ( $16 \%$ ) of these 25 patients presented with serum concentrations in the toxic range, a further nine $(36 \%)$ had concentra- tions of over $11 \mathrm{mg} / \mathrm{l}$; administration of $250 \mathrm{mg}$ aminophylline in these patients, which raises the serum concentration by about $9 \mathrm{mg} / 1,{ }^{4}$ would have taken the concentrations into the toxic range. In 12 of the 26 samples the theophylline concentration was already within the therapeutic range, which raises the question of whether aminophylline treatment was appropriate. Considerable benefit may be obtained by maintaining the theophylline concentration close to $20 \mathrm{mg} / 1,{ }^{1}$ but some workers suggest that beta adrenergic agonists may be more effective in acute asthma. ${ }^{5}$ For patients with initial concentrations of less than $10 \mathrm{mg} / \mathrm{l}$ an intravenous bolus followed by a maintenance infusion of aminophylline would clearly be beneficial, but monitoring of serum theophylline concentrations is necessary.

Details of daily doses of theophylline and serum concentrations after given times in 25 patients

\begin{tabular}{|c|c|c|c|}
\hline Case No & $\begin{array}{l}\text { Daily dose of } \\
\text { theophylline (mg) }\end{array}$ & $\begin{array}{c}\text { Time between dose } \\
\text { and blood sample } \\
\text { (hours) }\end{array}$ & $\begin{array}{l}\text { Serum theophylline } \\
\text { concentration }(\mathrm{mg} / \mathrm{l})\end{array}$ \\
\hline $\begin{array}{r}1 \\
2 \\
3 \\
4 \\
5 \\
6 \\
7 \\
8 \\
9 \\
10 \\
11 \\
12 \\
13 \\
14 \\
15 \\
16 \\
17 \\
18 \\
19 \\
20 \\
21 \\
22 \\
23 \\
24 \\
25\end{array}$ & $\begin{array}{l}708 \\
354 \\
708 \\
708 \\
354 \\
354 \\
708 \\
708 \\
708 \\
354 \\
708 \\
354 \\
531 \\
708 \\
708 \\
992 \\
354 \\
531 \\
354 \\
354 \\
531 \\
354 \\
577 \\
354 \\
885\end{array}$ & $\begin{array}{c}4 \frac{1}{2} \\
21 \\
9 \frac{1}{2} \\
3 \\
13 \frac{1}{2} \\
7 \frac{1}{4} \\
8 \\
13 \\
10 \frac{1}{2} \\
12 \\
9 \\
2 \frac{1}{2} \\
7 \frac{1}{2} \\
24 \\
4+ \\
101 \\
11 \\
2 \\
2 \\
5 \\
16 \\
1 \ddagger \\
6 \\
71 \\
2 \frac{1}{4} \\
4 \frac{1}{2}\end{array}$ & $\begin{array}{r}11 \cdot 8 \\
11.2 \\
2.0 \\
20.5 \\
10.8 \\
10.5 \\
6.2 \\
20.4 \\
11.9 \\
3.5 \\
14 \cdot 1 \\
11 \cdot 2 \\
2.0 \\
15.3 \\
31.2 \\
5.9 \\
2.0 \\
8.6 \\
18.1 \\
5.6 \\
3.6 \\
25.0 \\
11.1 \\
9.2 \\
17.0 \\
11.0\end{array}$ \\
\hline
\end{tabular}

- 4 hours, $+1 \frac{1}{2}$ hours, $\ddagger 1$ hour after aminophylline $250 \mathrm{mg}$ given intravenously.

This study confirms that almost half the patients who regularly take theophylline are at risk from theophylline poisoning when given an intravenous bolus of aminophylline. When such patients are admitted to hospital acutely ill it would be safer to start a maintenance infusion equivalent to the oral dose and await the result of assay of serum theophylline concentrations before giving a bolus of the drug. Giving aminophylline to such patients may be hazardous when monitoring facilities are not available. Many patients do not require a bolus, and for others an aminophylline infusion is inappropriate.

We thank Drs G J Addis and W McMurray, who gave helpful advice with the text, and Miss M Montgomerie for typing the manuscript. The EMIT assay kits were provided by Napp Laboratories.

1 Vozeh S, Kevitz G, Perruchoud A, et al. Theophylline serum concentration and therapeutic effect in severe acute bronchial obstruction: the optimal use of intravenously administered aminophylline. Am Rev Respir Dis 1982;125:181-4.

2 Powell JR, Vozeh S, Hopewell P, Costello J, Scheiner LB, Reigelman S. Theophylline disposition in acutely ill hospitalised patients. Am Rev Respir Dis 1978;118:229-37.

${ }^{3}$ Thomson PJ, Hay JG. Dangers of compound drugs and intravenous aminophylline. Lancet 1982 ;ii:1228.

4 Nicholson DP, Chick TW. A re-evaluation of parenteral aminophylline. Am Rev Respir Dis 1973;108:241-7.

${ }^{5}$ Rossing TH, Fanta CH, Goldstein DH, Snapper JR, McFadden ER. Emergency therapy of asthma: comparison of the acute effects of parenteral and inhaled sympathomimetics and infused aminophylline. Am Rev Respir Dis 1980;122:365-71.

(Accepted 10 November 1983)

Wythenshawe Hospital, Manchester M23 9LT

M FELICITY STEWART, BSC, MB, registrar in chemical pathology JOYCE BARCLAY, MB, MRCP, senior registrar in cardiothoracic medicine RAY WARBURTON, MSC, PHD, senior biochemist

Correspondence to: $\mathrm{Dr} M$ Felicity Stewart, Department of Chemical Pathology, Hope Hospital, Salford M6 8HD. 